\title{
PROJECT
}

\section{PROCEDURAL DUE PROCESS AND CAMPUS DISORDER: A COMPARISON OF LAW AND PRACTICE*}

\section{Contemporary Campus Milieu}

The phenomenon of campus-wide civil disorder has emerged upon either total procedural voids or traditional disciplinary systems created to punish individual transgressions, often of an academic nature. This strain on institutional capacity has been accentuated by the application of constitutional mandates resulting from the judicial review of collegiate discipline. Some institutions responded to these factors by creating specialized tribunals, composed of representatives from different segments of the academic community, to handle only cases arising from campus disorders. Undergraduate tribunals often became immersed in the complexities of procedural due process; the resulting difficulties sometimes necessitated the modification of existing procedures. Whatever the form taken by the reaction to civil disorders on campuses, it was generally guided by the desire to balance the constitutional demands for adequate procedures against the maintenance of institutional independence and integrity.

This project was designed to compile and compare the various procedural systems developed throughout the American college and university community. Extensive analysis of the procedural standards which have been considered constitutionally required was not attempted. These issues have been discussed in depth in the legal periodicals ${ }^{1}$ and are presented here only in summary for the purpose of comparison with the actual practices discovered.The project seeks to inform the educational community of the various approaches being used and to indicate the extent to which these schemes would withstand attack on the basis of current and developing judicial standards. The study recognizes that all institutions of higher learning

* This project was conducted under a research grant from the American Bar Foundation. The Journal wishes to express its,appreciation for this support from the Foundation; however, the analyses, conclusions, and opinions expressed are those of the authors, not those of the Foundation, its officers and directors, or others associated with its work.

1. A "selected bibliography on student rights" can be found in Van Alstyne, The Student as University Resident, 45 DENYER L.J. 582, 612-13 (1968). For an updating of the procedural due process portion of that bibliography, see Appendix A, page 808 infra. 
are not necessarily legally required to conform their procedures to provide the elements of due process. Public institutions are undoubtedly required to comply with constitutional standards as applied by the fourteenth amendment; applicability of the same standards to private institutions depends on whether their activities are considered "state action," an issue of intense contemporary debate, the relevant arguments being outlined below. ${ }^{2}$ However, it is assumed that most schools, whether required by law or not, desire to provide procedures that are fundamentally fair within the context of their individual needs. It is hoped that this project will be instrumental in furthering that end.

The methodological technique employed was quite simple. A questionnaire ${ }^{3}$ was mailed to every college or university, accredited or unaccredited, known to the American Council on Education with the exception of approximately two-hundred addressees who were either military installations, theological seminaries, or other institutions determined to be unrepresentative. Solicitations were made to 2,115 institutions, and 572 or 27 percent replied although only 536 replies were usable. The questionnaire requested a copy of the procedural system employed by the institution and answers to 69 specific questions. ${ }^{4}$ Replies to the questionnaire ranged from sophisticated procedural compendia to a complete lack of written procedures or regulations. Reasons for dispensing with any written standards varied from the divine-right concept that atttending college is a privilege, not a right, thereby justifying immediate suspension of those challenging the administrative hierarchy, ${ }^{5}$ to the belief that written procedures

2. See pages 795-807 infra.

3. The questionnaire and the results of the survey are reprinted in the Appendix B, page 811 infra.

4. To understand the statistics utilized throughout the project, one must be aware of the distinction between the total "replies" received and the "responses" contained in such replies. Except where indicated, all percentages are derived from the total number of replies to a question. The total will, therefore, be composed of percentages for positive responses plus a percentage for the "no responses" to the partieular question. Since most of the "no responses" probably indicate an absence of the particular procedure solicited, ignoring them would have created a distorted picture of actual campus due process.

5. The following quotations from replies are intended only to illustrate the widely divergent views on this subject and are not meant to criticize the approach taken by any school. "We say that attendanee at University is a privilege and not a right, and any student who violates that privilege either by a breach of regulations or by an attempt to stir up rebellion leading to open defianee and hostility would be expelled immediately and without question." Questionnaire Reply. 
breed unlawful activity and endanger civil liberty, ${ }^{6}$ a concept that the drafters of the Bill of Rights rejected almost two-hundred years ago. Many schools expressed a desire to develop disorder guidelines patterned on the questionnaire; 7 others indicated faith in the more fundamentalist approach of relying on "the bible and the law." One of the more surprising replies came from a school of criminal justice which had not yet developed any specific regulations. ${ }^{8}$

\section{Emergence of Student Procedural Rights}

In 1961, the Court of Appeals for the Fifth Circuit in Dixon $v$. Alabama State Board of Education ${ }^{9}$ held that the fourteenth amendment required that tax-supported colleges give students notice and an opportunity to be heard before they could be expelled for nonacademic misconduct. ${ }^{10}$ This decision represented a departure from existing case law in the area; earlier cases had not considered whether notice and a hearing were required but had focused instead on the question whether the particular hearing and notice provided were adequate to prevent arbitrary and capricious action by colleges in

6. Our aim is to govern the campus according to civil libertarian principles and to add as few regulations as possible to those laws of the community that already apply to students as citizens. ... [W] have even very deliberately avoided any fancy kind of "contingency planning" when faced with the prospect of disturbance, despite pressures to the contrary. . . ." "[D]eliberations concerning [contingency] plans and especially their publication can have a provocative effect. . . . There is the risk, in sum, that contingency plans will become selffulfilling prophecies. . . . If and when the need arises [for disciplinary actions], which I hope never happens (your questionnaire describes a chamber of legalistic horrors that must have devastating effects on an academic community), our commitment to civil libertarian principles would require the guarantee of due process. Id.

7. Although the questionnaire was intended to be neutral, several schools found it to possess substantive import. "I have retained the questionnaire as a guideline for us." "I would like to retain the text of the questionnaire to use as guidelines for discussions that would lead to formal regulations insuring due process for our students in this area." "We have been discussing procedures such as you are concerned with because we are well aware that approaches such as ours will soon go the way of the dinosaurs, even in such sheltered enclaves as this. With your permission 1 would like to retain the questionnaire as an indication of what we may have to deal with." Id. But see "After attempting to answer the questionnaire, I find that the philosophical approach is incompatible with our operation. We view our hearing board not as a court of law, but rather as a place to ascertain facts and attitudes and communicate expectations. . . . l hope we don't forfeit our position and join the legal approach." Id. Another reply interpreted the questionnaire as urging the "civil rights" approach.

8. "We do not, at the present time, have any specific set of regulations governing behavior although our general policy is to permit students full privacy, right to counsel, and all other due process privileges in any student discipline cases. $I d$.

9. 294 F.2d I50 (5th Cir.), cert. denied, 368 U.S. 930 (1961).

10. Id. at 151 . 
dismissing students. ${ }^{11}$ The court, however, in overcoming the judiciary's traditional reluctance to delve into the conundrum of academic due process, left unanswered many questions concerning students' procedural rights. It required only that a student under threat of expulsion for engaging in campus disturbances be provided a statement of specific charges which, if proved, would justify such a penalty. A hearing containing procedural safeguards greater than those present in an informal interview, but less than those of a "fulldress judicial hearing," was also required..$^{12}$ Although implying that the right of cross-examination was not constitutionally compelled, ${ }^{13}$ the opinion did not discuss whether the student at the hearing had a right to counsel, a privilege against compulsory self-incrimination, the right to appellate review with a college-furnished transcript to expedite such review, the right to confront witnesses against him, or the right to require an open hearing. Nor did Dixon consider the perplexing questions concerning student rights outside the hearing, such as discovery and interim suspension, or determine the severity of sanction that had to be threatened before the Constitution required the procedural safeguards outlined by the court.

In the period from 1961 to the present the judiciary has struggled with these questions, but their answers and the resulting guidelines for colleges have been far from clear. In balancing the students' interests against those of the institution, the courts have arrived at widely divergent results. The value of the following exposition of the present state of the law is, therefore, a guide to the minimal procedure an institution should provide in order to avoid court interference in a university's handling of campus disorders.

\section{Procedural Rigïts Prior to the Hearing}

\section{Regulations Governing Disorder}

While the content of regulations governing campus disorders is a

11. See, e.g., Steier v. New York State Educ. Comm'r, 271 F.2d 13 (2d Cir. 1959), cert. denied, 361 U.S. 966 (1960); Carr v. St. John's Univ., 34 Misc. 2d 319, 231 N.Y.S.2d 403 (Sup. Ct.), rev'd 17 App. Div. 2d 632, 231 N.Y.S.2d 410, affd mem., 12 N.Y.S.2d 802, 187 N.E.2d 18, 235 N.Y.S.2d 834 (1962). See also Anthony v. Syracuse Univ., 224 App. Div. 487, 231 N.Y.S. 435 (1928).

12. $294 \mathrm{~F} .2 \mathrm{~d}$ at 159 . It is clear from the cases, however, that a university need not charge all participants in a demonstration and may prosecute only the instigators of disruptive activities when such persons can be identified. See, e.g., Zanders v. Louisiana State Bd. of Educ., 281 F, Supp. 747, 767 (W.D. La. 1968). The college, in other words, need not dismiss half the enrollment in order to expel the few students mainly responsible for the disruption.

13. 294 F.2d at 159. 
substantive matter largely beyond the pale of the present inquiry, the existence of rules is a basic issue of procedural due process. If no guides to proper conduct exist, the procedures for punishing conduct later determined to be illegitimate are fundamentally defective. The necessity for published rules is actually a matter of some dispute; for example, the authors of the recent Report of the American Bar Association Commission on Campus Government and Student Dissent were unable to assert "either that a university may never act against a student other than pursuant to a published rule clearly furnishing the basis for a specific charge or that it may freely act against the student even in the absence of any clearly applicable and previously published rule."'14

Without venturing into questions concerning unconstitutional vagueness and overbreadth, ${ }^{15}$ the questionnaire asked whether the institution published regulations governing campus disorders. Sixtysix percent ${ }^{16}$ of the schools responding to the questionnaire indicated that they provided and published regulations applicable to campus disorders. While the regulations varied substantially from those providing minimal notice to detailed specificity, it is significant that 27 percent of the replying institutions did not even provide students with minimal written guidelines of acceptable behavior concerning campus disorders. Failure to provide such guidelines highlights the punitive rather than the preventive functions of such university authorities. Although detailed codification of campus regulations may be undesirable, ${ }^{17}$ the presence of even general guidelines might educate students as to likely responses of campus authorities to certain activities and possibly deter confrontations designed to "test" the university administration's resolve or to solicit the university's position on fundamental issues. Arguably, the absence of substantive campus disorder regulations necessarily emphasizes reliance on an ability to react to disorders rather than on the utilization of foresight in attempting to prevent needless confrontation through an informed student body.

14. Report of the american Bar Association Commission on Campus Government AND STUdent Dissent 21 (1970) [hereinafter cited as ABA Report].

15. Three of the recent writings in the vagueness-overbreadth area are Note, Uncertainty in College Disciplinary Regulations, 29 Oно ST. L.J. 1023 (1968); 4 GA. L. REv. 221 (1969); 40 U. COL. L. Rev. 453 (1968).

16. All percentages specified in this project are contained in the "Sample Questionnaire and Summary of Results" in Appendix B infra.

17. See ABA REPORT 21 . 


\section{Notification of Charges}

Some courts have held that students who are charged with violating college regulations concerning campus disorders must be notified in writing ${ }^{18}$ at least one week before the hearing ${ }^{19}$ and that the notice must specify the grounds upon which the charge is based.20 However, if the student cannot be located after a good faith, diligent effort, there is authority for the proposition that he need not actually receive notice before expulsion. ${ }^{21}$ The reason for imposing these safeguards is, of course, to provide the student adequate time and information to be able to prepare a defense to the charges against him..$^{22}$ To insure the fundamental fairness that the fourteenth amendment requires and that informed decisions are made in what are basically factual disputes, the student must be allowed to marshal his evidence. To this end, the student should be furnished the names of the witnesses against him, ${ }^{23}$ at least where a complete adversary proceeding is not a requirement, and be allowed to inspect affidavits

18. General Order on Judicial Standards of Procedure and Substance in Review of Student Discipline in Tax Supported Institutions of Higher Education, 45 F.R.D. 133 (W.D. Mo. 1968) (en banc) [hereinafter referred to as General Order]; Scoggin v. Lincoln Univ., 291 F. Supp. 161, 171 (W.D. Mo. 1968) (citing General Order); see Esteban v. Central Mo. State College, 277 F. Supp. 649, 651 (W.D. Mo. 1967), aff d 415 F.2d 1077 (8th Cir. 1969), cert. filed, 38 U.S.L.W. 3256 (U.S. Jan. 13, 1970), noted in 49 NEB. L. REV. 689 (1970). See generally 4 GA. L. REV. 221 (1969).

19. In Esteban v. Central Mo. State College, 277 F. Supp. 649, 651 (W.D. Mo. 1967), and Schiff v. Hannah, 282 F. Supp. 381,383 (W.D. Micb. 1966), it was held that 10 days notice was required. However, less time has been approved by the courts. See, e.g., Zanders v. Board of Educ., 281 F.Supp. 747, 760 (W.D. La. 1968) (one week); Jones v. Board of Educ., 279 F. Supp. 190, 199 (M.D. Tenn. 1968), aff d 407 F.2d 834 (4th Cir. 1969), petition for cert. dismissed, 397 U.S. 31 (1970) (two days); Due v. Florida A. \& M. Univ., 233 F. Supp. 396, 398-99 (N.D. Fla. 1963) (at hearing).

20. Dixon v. Alabama State Bd. of Educ., 294 F.2d 150, 158 (5th Cir. 1960); Woody v. Burnus, 188 So. 2d 56, 58 (Fla. Ct. App. 1966).

21. In Wright v. Texas So. Univ., 277 F.Supp. 110 (S.D. Tex. 1967), affd. 392 F.2d 728 (5th Cir. 1968), the plaintiffs, who had been involved in a campus disturbance, had changed their addresses without notifying the university, thereby violating a university regulation. The Dean in one instance personally asked plaintiff Wright to talk with him; when Wright did not appear the Dean found that even Wright's family did not know of his whereabouts. A university letter to plaintiff Richards was returned undelivered. Sucb attcmpts were held sufficient by the court to satisfy due process requiremcnts. Id. at 112-13.

22. In one case, the notice was required to contain reference to the specific university rule allegedly violated. See Zanders v. Louisiana State Bd. of Educ., 281 F. Supp. 747 (W.D. La. 1968).

23. Dixon v. Alabama State Bd. of Educ., 294 F.2d 150 (5th Cir. 1961). 
or exhibits which the college intends to submit at the pending hearing. ${ }^{24}$ However, there is no authority to support an institutional demand to inspect a student-defendant's documents and to acquire the names of his witnesses. ${ }^{25}$

Seventy-nine percent of the colleges and universities replying indicated that they provided an accused student with a written statement of the charges against him. Only 24 percent gave at least seven days notice as required by some courts although 55 percent of those replying acknowledged that they gave at least two days notice. Only nine percent provided less than two days notice. Seven percent asserted that they provided written notice but failed to indicate any time period, possibly indicating a lack of formal, consistent procedures. Approximately 80 percent had an established procedure for conveying notice of charges to a student, the methods varying from ordinary mail to personal interview. Fifty-two percent of those reporting also provided students with the names of adverse witnesses, and 57 percent permitted the examination of affidavits, exhibits, and statements of complaining witnesses prior to the hearing. Though there is no legal authority to support such a claim, 44 percent of the replying schools claimed a similar prerogative to inspect student documents and acquire the names of student witnesses.

\section{Searches and Seizures}

The question of whether the fourth amendment should or will be applied to prevent university officials from conducting warrantless searches of students' dormitory rooms is currently unresolved. ${ }^{26}$ The

24. Esteban v. Central Mo. State College, 277 F. Supp. 649, 651 (W.D. Mo. 1967). See Frank v. Marquette Univ., 209 Wis. 372, 245 N.W. 125 (1932). In Frank, the plaintiff, having been denied a diploma, sought to acquire university records concerning disciplinary sanctions placed on other students who had received diplomas. Access was denied because he could not show the materiality of the documents sought to the issue of whether the university acted arbitrarily in denying him a diploma, thus implying that had this showing been made, he would have succeeded. See generally Van Alstyne, supra note 1; Note, Reasonable Rules, Reasonably Enforced-Guidelines for University Disciplinary Proceedings, 53 MiNN. L. Rev. 301, 323-24 (1968).

25. Possibly no university has ever made such a demand. At any rate, in most cases the question will likely be moot because the University will probably control all the pertinent information.

26. See Comment, Pablic Universities and Due Process of Law: Students' Protection Against Unreasonable Search and Seizure, 17 KaNSAS L. REv. 512 (1969); 53 MiNN. L. REv., supra note 24, at 324. See also Note, College Searches and Seizures: Privacy and Due Process Problems on Campus, 3 GA. L. Rev. 427 (1969); Note, The Relationship of the Fourth Amendment to Student Disciplinary Hearings, 30 U. PrTT. L. Rev. 561 (1969). 
limited authority available indicates that the student cannot prevent college officials from searching his room in his presence where the college reasonably believes that the room is being used for an illegal purpose. In Moore v. Student Affairs Committee of Troy State University, ${ }^{27}$ the court refused to apply the exclusionary rule at a subsequent disciplinary hearing to bar the introduction into evidence of marijuana found as a result of a warrantless search of a student's room. In balancing the student's right to be free from unreasonable searches against the university's obligation to insure campus order and maintain an educational atmosphere, the court found the college regulation permitting such searches reasonable and upheld it..$^{28}$

Though at the present time neither the fourth amendment nor the exclusionary rule applies to protect students at university disciplinary hearings, 50 percent of the schools replying indicated that their hearing boards could not consider evidence obtained in violation of law or university regulations. Only 16 percent indicated that they would use such evidence, the remainder failing to respond.

\section{Miranda Warnings}

Similarly, the strictures of the fifth amendment have seldom been successfully imposed on university activities prior to disciplinary hearings. No case has held that a student subject to university sanctions must be advised of his procedural rights. ${ }^{20}$ Since the application of the privilege against self-incrimination at the hearing is itself problematic ${ }^{30}$ there is little reason to suppose that Miranda ${ }^{31}$ will apply to college disciplinary proceedings. The courts have

27. 284 F. Supp. 725 (M.D. Ala. 1968); see 3 GA. L. Rev. 223 (1968).

28. The court rejected the in loco parentis and contractual theories of student-university relationship, but nevertheless stated that the university "may infringe to some extent on the outer bounds of the Fourth Amendment rights of students" in holding the criminal standard of probable cause inapplicable. $284 \mathrm{~F}$. Supp. at 729 . The case has been soundly critieized by the commentators on the ground that the university was not forced to justify its regulation by showing that there were no effective, less drastic alternatives or that the benefits to the university accruing from the rule outweighed its detrimental effects on students. See note 26 supra. See also People v. Kelly, 195 Cal. App. 2d 669, 16 Cal. Rptr. 177 (Ct. App. 1961); People v. Overton, 20 N.Y.2d 360, 283 N.Y.S.2d 22, 229 N.E.2d 596 (1967).

29. In Buttny v. Smiley, 281 F. Supp. 280 (D. Colo. 1968), the court stated that it knew of "no legal authority that requires university officials to advise a student involved in diseiplinary proceedings of his right to remain silent . . . ." Id. at 287. See General Order, supra, note 18, at 147; 40 U. Colo. L. Rev. 453 (1968).

30. See notes 107-109 infra and accompanying text.

31. Miranda v. Arizona, 384 U.S. 436 (1966). 
repeatedly stated that the procedure for expulsion need not contain all the safeguards inherent in a criminal proceeding ${ }^{32}$ because to so rule would be "impractical and detrimental to the educational atmosphere and functions of a university." ${ }^{33}$ From this point of view, Miranda's application could easily be seen as infringing too extensively upon university autonomy and the educational process and as unnecessary in most cases to insure fairness. ${ }^{34}$

The colleges and universities replying to the questionnaire indicated a mixed commitment to fifth amendment principles. Although 77 percent declared that a student had the right to remain silent during any pre-hearing investigation, while only two percent did not provide this right, only 51 percent indicated that silence would not be commented on at the hearing, and 19 percent answered that they would comment. Perhaps a substantial number of the "no responses" to these questions are the product of an unwillingness to deny what is generally deemed to be a fundamental individual right. Fifty-seven percent of the replying schools indicated that a student was warned of his right to remain silent and of the possibility of self-incrimination during pre-hearing investigations, a procedure surpassing the rights provided by present case law in the area. Only 17 percent responded that such a warning was not given. The results of the questionnaire certainly indicate that colleges and universities have in some instances substantially exceeded the judicary in protecting students from compulsory self-incrimination.

\section{Concurrent University-Criminal Jurisdiction}

Delay of University Prosecutions. Students have been unsuccessful in enjoining the initiation of university hearings until after the completion of local criminal prosecutions brought as a result of disruptive campus activity ${ }^{35}$ Students subject to both university

32. See, e.g., Dixon v. Alabama State Bd. of Educ., 294 F.2d 150, 159 (5th Cir. 1960); Goldberg v. Regents of the Univ. of Calif., 248 Cal. App. 2d 867, 881, 57 Cal. Rptr. 463, 473 (1967).

33. 248 Cal. App. 2d 867, 881, 57 Cal. Rptr. 463, 473 (1967).

34. See General Order, supra note 18, at 147. But see Note, Admissibility of Testimony Coerced by a University, 55 CORNELL L. Rev. 435 (1970).

35. See, e.g.. $248 \mathrm{Cal}$. App. 2d 867, 57 Cal. Rptr. 463. The court stated that it could not "accept the contention that where certain conduct is violative of both the rules and regulations of the university and the statutes of the state that the discipline imposed by the academic community must wait the outcome of the other proceedings." $248 \mathrm{Cal}$. App. 2d at $885,57 \mathrm{Cal}$. Rptr. at 476 . The petitioner, as a result of his activities in organizing and participating in a 
and criminal sanctions have argued that if the university procedures are not delayed, they could be forced to render statements before a disciplinary hearing which could subsequently be used against them in local criminal proceedings. ${ }^{36}$ This argument has not been accepted because the alleged injury has been deemed too speculative. The students may not necessarily be forced to incriminate themselves in order to avoid expulsion, and, in the event such statements are made, they will not necessarily be introduced in a subsequent criminal proceeding. ${ }^{37}$ Further, if incriminating statements are made and subsequently introduced as evidence, at least one court has assumed that a student may invoke Garrity v. New Jersey ${ }^{38}$ in opposition to the prosecutor's proffer in the criminal action..$^{39} 1 \mathrm{t}$ seems clear, therefore, that the assertion of fifth amendment privileges will be insufficient to delay administrative disciplinary proceedings.

University Punishment for Violating Local Laws. A closely related problem to the issue of delay is that of university sanctions imposed on students for violations of local law. Although vigorously critieized, ${ }^{40}$ the cases indicate that the imposition of university

campus rally at which he was moderator, was charged with "unbecoming behavior" by the university and with violation of the obscenity statute and disturbing the peace by the local authorities.

36. See Grossner v. Trustees of Colum. Univ., 287 F. Supp. 535, 550 (S.D.N.Y. 1968). The students' argument failed because at the hearing they could bave stood mute and because the hearing had not yet been held, thus-rendering any fifth amendment claims speculative. See notes 107-109 infra and accompanying text.

37. See Furutani v. Ewigleben, 297 F. Supp. 1163 (N.D. Cal. 1969).

38. 385 U.S. 493 (1967). In Garrity, police officers questioned concerning traffic ticket fixing were confronted with the choice of either incriminating themselves or losing their jobs under a statute providing for the removal of offieials who refused to answer questions before a commission investigating the official's conduct in office. The Supreme Court held that statements made under these circumstances were coerced and therefore inadmissible in subsequent prosecutions. Although the case seems analogous to the student's situation, its applicability is by no means assured to protect the student's fifth amendment privilegcs. Moreover, it is highly unlikely that a student would be willing to make incriminatory statements relying solely on Garrity in an attempt to remain in school. To this extent, the rationale of Furutani v. Ewigleben, 297 F.Supp. 1163 (N.D. Cal. 1969), seems deficient.

39. 297 F. Supp. at 1165.

40. See Monypenny, Toward a Standard for Student Academic Freedom, 28 LAW \& Contemp. Prob. 625, 629 (1963); Van Alstyne, supra note 1; Wright, The Constitution on the Campus, 22 V AND. L. REv. 1027, 1068-69 (1969). The unifying theme of the commentators on this point is that no purpose is served by an additional university prosecution unless the college has a distinct interest to be protccted which has not bcen vindicated by public prosecution. As an example, the student convicted of selling heroin should be compared with the situation of a student charged with contempt of court. An additional university prosecution in the latter case resulting in expulsion would serve no distinet interest, but in the former situation, such an interest is rcadily discernible. 
sanctions in this situation is permissible. ${ }^{41}$ The rationale for this position grows out of what has come to be recognized as the university's inherent rule-making authority.$^{42}$ Since it is ostensibly the university's function to provide a learning environment both for the individual student and the academic community, the college necessarily has the responsibility of controlling, without impairing students' constitutional rights, student activities which impede the achievement of these goals. To this end, the university can formulate its own standards, rewards, and sanctions in keeping with its educational objectives. Hence, the power arises in the university to punish conduct which endangers the learning process. The problem, however, is that in many instances the college has viewed its interests as unnecessarily broad and has needlessly punished off-campus student activities violative of the law.$^{43}$ Still, courts have granted colleges wide discretion in this area.4

Though not prohibited by law from prosecuting parallel administrative actions against students charged with breaches of criminal law, eight percent of the schools replying had at least generally abandoned their prerogative. Twenty-three percent indicated that they would prosecute within the university community regardless of the existence of contemporary criminal prosecutions. University sentiment is clearly divided as to whether to pursue such administrative actions. Eight percent of the schools replied that their decision to prosecute depended on the offense charged, while 14 percent normally wait until after the criminal trial to bring any action. This deferral may or may not be to the student's advantage depending upon the university's approach. Several schools indicated that they would not prosecute if they were "satisfied" with the action of the courts. This practice is objectionable insofar as the university becomes a court of "higher justice" and may effectively negate the procedural rights of the student in the criminal action. 1t would seem that the university which has deferred its action should not in any case prosecute if the student is acquitted in the civil courts. Though parallel

41. See Duev. Florida A. \& M. Univ., 233 F.Supp. 396 (N.D. Fla. 1963); Knight v. State Bd. of Educ., 200 F. Supp. 174 (M.D. Tenn. 1961).

42. See Buttny v. Smiley, 281 F. Supp. 280, 285 (D. Colo. 1968); Zanders v. Board of Educ., 281 F. Supp. 747, 757 (W.D. La. 1968); 248 Cal. App. 2d 867, 874, 57 Cal. Rptr. 463, 468; Morris v. Nowotny, 323 S.W.2d 301,312 (Tex. Civ. App. 1959).

43. See 233 F. Supp. 396 . See note 40 supra.

44. See note 41 supra and accompanying text. 
actions are not unlawful, some universities apparently believe that it is unfair or wasteful of university resources to pursue them.

\section{Interim Suspension}

A problem concerning student pre-hearing rights which has arisen recently involves "interim suspension," that is, the practice of suspending a student without a full hearing pending the initiation of a subsequent disciplinary proceeding.5 In Stricklin $v$. Regents of University of Wisconsin ${ }^{46}$ the court stated that a university's interim suspension power could be invoked only in the case of a campus emergency in which the safety of both students and university property was seriously threatened..$^{47}$ In addition, the district court in Stricklin ${ }^{48}$ determined that interim suspensions must be preceded by a

45. Stricklin v. Regents of Univ. of Wis., 297 F. Supp. 416, 419 (W.D. Wis. 1969).

46. Id. at 416; $c f$. Marzette v. McPhee, 294 F. Supp. 562 (W.D. Wis. 1968). An earlier case which considered the problem was Vermillion v. State ex rel. Englehardt, $78 \mathrm{Neb}, 107,110$ N.W. 736 (1907), in which an interim suspension was upheld, pending a complete hearing, to preserve order in the school. The precedential validity of the case is doubtful, however, because the court seemed to rely in part at least on the in loco parentis doctrine, which has been largely discarded by later decisions. See, e.g., Dixon v. Alabama State Bd. of Educ., 294 F.2d 150 (5th Cir. 1961); Zanders.v. Board of Educ. 281 F. Supp. 747 (W.D. La. 1968).

47. The court in Stricklin, 297 F. Supp. at 420, relied heavily on the Joint Statement on Rights and Freedoms of Students approved by numerous professional educational associations, which states that pending disciplinary hearings, the student's status should not be altered "except for reasons relating to his physical or emotional safety and well-being, or for rcasons relating to the safety and well-being of students, faculty, or university property." Van Alstyne, supra note 1 , at 595 .

In Marzette v. McPhee, 294 F. Supp. 562 (W.D. Wis. 1968), students had seized and ransacked the President's office, verbally abused him, and had also seized another building, thereby causing such confusion that the university had to be closed temporarily. In Stricklin, violent rioting had occurred, but the court held that the temporary suspension of a student for as long as thirteen days without a hearing violated due process requirements as set forth in Dixon and deprived the student unjustifiably of an opportunity to show mistaken identity, extreme provocation, or other reason for withholding the interim suspension.

48. 297 F. Supp. at 420. Cf. Lafferty v. Carter, 310 F. Supp. 465, 469-70 (W.D. Wis, 1970). A recent Oklahoma statute indieates that the judicial faith in the significance of at least a preliminary hearing before a temporary suspension is not shared by all. OKLA. STAT. ANN. tit. 75, § 301 (Supp. 1969) provides that

a student in a state-supported institution of higher learning against whom a disciplinary proceeding shall have been commenced upon sworn affidavit on one of the following grounds of misconduct, may forthwith be barred from the campus and be removed from any college or university-owned housing, pending final disposition of the proceeding against him:

1. participation in a riot as defined by the penal code;

2. possession or sale of any drugs or narcotics prohibited by the penal code;

3. wilful destruction of or wilful damage to state property; 
preliminary hearing to determine whether the continued presence of the charged students on the campus would endanger persons and property unless the situation on campus is such that conducting such a hearing would be unreasonably difficult. In such cases preliminary hearings must be held at the "earliest practical time."49

Even the limited endorsement that Stricklin provides for interim suspension without preliminary hearing ${ }^{50}$ might be questioned under the reasoning of the recent Supreme Court case, Goldberg v. Kelly.51 In Goldberg the Court rejected the interim suspension of welfare payments without a preliminary hearing, balancing the recipient's interest in avoiding loss of the payments against the government's interest in summary preliminary adjudication..$^{52}$ The Court did indicate that some governmental benefits might be suspended without such a hearing where the individual's interest was deemed less important than any potential harm to the public.$^{53}$ lncluded as actions that might be taken without a preliminary hearing were suspension of exemption from a stock registration requirement, seizure of mislabeled vitamin products, withdrawal of a contractor's right to do business with the government, and dismissal of a public employee by the federal government. ${ }^{54}$ Though it might be argued that a student has a "property" right in the completion of his education because of the critical nature of an education in today's society ${ }^{55}$ and that such right is sufficiently similar to that of a welfare recipient's benefits to justify the requirement of a preliminary hearing, ${ }^{56}$ the student's right to an education is not being withdrawn by his temporary suspension from college..$^{57}$ The state's interest in the protection of individual students, the property of such students, and public property would seem to be greater than its interest in preventing the potential loss of

4. unauthorized presence in or occupation of any part of the campus after resisting an order to leave by duly constituted authority[.]

This "barring" of a student from campus, like the withholding of bail, might deprive a student of an opportunity to prepare a proper defense. $C f$. Stack v. Boyle, 342 U.S. 1, 4 (1951).

49. 297 F. Supp, at 420 .

50. See note 48 supra and accompanying text.

51. Goldberg v. Kelly, 397 U.S. 254 (1970). See generally 33 AlBaNy L. Rev. 616 (1969).

52. 397 U.S. at 266.

53. Id. at 263 n. 10 .

54. $I d$.

55. Cf. id. at 262 n.8; Dixon v. Alabama State Bd. of Educ., 294 F.2d 150, 157 (5th Cir. 1961); 1969 DUKE L.J. 1285, 1291.

56. Cf. 1969 Duke L.J. at 1291.

57. But cf. 294 F.2d 157. 
public funds before $a^{\circ}$ full hearing in the public welfare context. As long as summary suspension is strictly circumscribed, it is reasonable for the university to have some leeway in the most intolerable circumstances to act without a preliminary hearing. Since such a summary suspension would not deprive a student "of the very means by which to live,"58 it is doubtful that the Supreme Court would extend Goldberg's requirements to the campus disorder context.

The question of the form of a preliminary hearing has not been fully answered, but the Stricklin court indicated in Buck v. Carteris that the requirement is satisfied by providing a student an early opportunity to appear before a single officer or an agency of the university to be informed of the nature of the offense. The student should also be allowed to make a statement before any decision on preliminary suspension is reached. Admission of guilt would justify no further steps before suspension, ${ }^{60}$ but a detailed denial supported by names of witnesses would probably require further investigation." A plausible explanation constituting an excuse or justification for continued presence on the campus might require a broader revelation by the university authorities of the source and nature of adverse information and possibly even necessitate confrontation with accusers.2.$^{62}$ But the absence of a straightforward denial, explanation, or excuse justifies withholding a detailed description of the nature and source of the charges. Although the law is far from settled in this area, $B u c k$ is recommended as an excellent guide for those administrators who desire to be apprised of future possibilities. ${ }^{63}$

Of the schools replying, 62 percent maintained the right to suspend a student in the interim between the bringing of charges and

\footnotetext{
58. 397 U.S. at 264.

59. Buck v. Carter, 308 F. Supp. 1246, 1248 (W.D. Wis. 1970).

60. Id. at 1249.

61. Id.

62. Id.

63. The opinions in Marzette, Stricklin, and Buck were authored by Judge Doyle sitting in the western district of Wisconsin. In the welfare area the Supreme Court recently cndorsed a proceding devoid of a complete record and a comprehenisve opinion as the standard for a preliminary hearing. 397 U.S. at 271 . Presumably, no morc would be required by the Supreme Court of a preliminary hearing in the campus disorder context since the purpose of the preliminary welfare hearing, to determine the grounds for the discontinuance of payments and to avoid erroneous termination, $i d$. at 266 , is seemingly an appropriate purpose of a campus preliminary hearing, that is to determine the grounds for suspension or withdrawal of financial aid and to avoid erroneous termination of such benefits.
} 
the holding of a formal hearing. Twenty-one percent indicated that they would not apply such a procedure. Although the grounds for invoking interim suspension were extremely varied, 45 percent of the responses appear to meet the legal test of an emergency situation where the safety of students and university property is involved. The other grounds listed in the summary results are clearly outside the mandate of the law. ${ }^{64}$ Fifty-two percent of the schools replying had at least an informal procedure for appeal or review of interim suspensions, while 11 percent declared that no review or appeal of interium suspension is provided, a procedure not in compliance with legal requirements.

\section{Procedural Rights at the Hearing}

\section{The Requirement of a Hearing}

Students under threat of expulsion ${ }^{65}$ for nonacademic ${ }^{66}$ offenses must be afforded a hearing which allows the administrative authority to hear the position of both the college and of the charged students. ${ }^{.7}$

\footnotetext{
64. For exposition of all the grounds provided by replying sehools see the SAMPLE Questionnaire and Summary of Results, question 3(k), in the Appendix B infra.

65. It is clear that if a student is threatened with expulsion or suspension for a significant length of time, a hearing must be afforded. See 297 F. Supp. 416; Soglin v. Kauffman, 295 F. Supp. 978 (W.D. Wis. 1968). In Stricklin a suspension for 13 days was held to require a prior hearing. The commentators have uniformly suggested that due process most likely does not require a hearing when only minor sanctions, such as social probation, minor fines, or loss of automobile privileges, are threatened. Professor Van Alstyne has stated that " $[w]$ here the consequence of error is relatively insubstantial, protection against the risk of error through the use of elaborate quasi-judicial procedures is subject to a constitutional trade-off with the need for administrative and fiscal economy." Van Alstyne, The Demise of the Right-Privilege Distinction in Constitutional Law, 81 HaRv. L. Rev. 1439, 1454 (1968). See Wright, supra note 40, at 1069-70. See also General Order, supra note 18, at 142.

66. Courts have traditionally been reticent to interfere in university determinations of academic achievement. See, e.g., Connelly v. Univ. of Vt., 244 F. Supp. 156 (D. Vt. 1965). The eourt stated that college authorities were given absolute discretion in determining whether a student has been delinquent in his studies," and that in such a case the burden was on the student to show "arbitrariness, capriciousness, or bad faith." Id. at 160. See also Lesser v. Board of Educ., 18 App. Div. 2d 388, 239 N.Y.S.2d 776 (1963); People ex rel. Bluett v. Board of Trustees, 10 11l. App. 2d 207, 134 N.E.2d 635 (1956); Wright, supra note 40, at 1069-70.

67. In Dixon, the court held that "due process requires notice and some opportunity for hearing before students at a tax-supported college are expelled for misconduct." 294 F.2d at 151. A ccord, Esteban v. Central Mo. State College, 277 F. Supp. 649 (W.D. Mo. 1967); Knight v. Board of Edue., 200 F. Supp. 174 (M.D. Tenn. 1961). Some states statutorily require that public school students threatened with expulsion be afforded a hearing. See, e.g., MASS. GEN. Laws ANN. ch. 76, § 17 (1968); PA. Stat. ANN. tit. 24, § 13-1318 (1962). See generally General Order, supra note 18; A nnot., 58 A.L.R.2d 903 (1958); cf. Healy v. James, 38 U.S.L.W. 2599 (D.C. Conn. April 24, 1970).
} 
The rationale for this rule lies in the fourteenth amendment procedural due process requirement as first applied on campuses in Dixon where the court found it shocking that a student could be denied the basic protections afforded a pickpocket. ${ }^{68}$ The court stated that even if the student's interests in remaining in college did not amount to a "right" he must be given an opportunity to be heard to protect against the arbitrary application of college regulations, albeit reasonable ones.$^{70}$ Furthermore, the university cannot circumvent the hearing requirement by conditioning the student's matriculation on a waiver of that right, since the court in Dixon explicitly stated that "the state cannot condition the granting of even a privilege upon the renunication of the constitutional right to procedural due process."

ln response to a question concerning actual practices regarding formal hearings, only 70 percent of the schools replying indicated that they had a formal hearing procedure applicable specifically to campus-wide disorders, while 22 percent answered that they had no formal procedure to handle such an eventuality. Presumably, such schools would revert to traditional campus disciplinary methods for procedures to apply to campus disorders. But the absence of any formal hearing procedure enhances the possibility that arbitrary and capricious action might be attempted by campus authorities since traditional procedures are inherently inappropriate in an emergency situation. Despite the hearing requirement, some state legislatures have passed laws in response to student disorders which provide for expulsion of a student without a hearing, ${ }^{72}$ a practice rejected by present case law.

68. 294 F.2d at 158. The court was quoting Seavey, Dismissal of Students: "Due Process," 70 HARV. L. REV. 1406, 1407 (1957).

69. The court quoted Cafeteria and Restaurant Workers Union v. McElroy, 367 U.S. 886, 894 (1961), to the effect that one "may not have a constitutional right to go to Bagdad, but the Government may not prohibit one from going there unless by means consonant with due process of law." 294 F.2d at 156.

70. 294 F.2d at 157.

71. Id. at 156.

72. See, e.g., LA. Rev. Stat. ANn. § 17:310 (1963).

Any student . . . of any institution of higher learning in this state . .

(5) ... may be expelled ... . from such institution effective immediately upon written notification of expulsion . . . signed by the president . . . and delivered to the [student's] last known address. Any person so . . expelled shall have the right to appeal. . . Id. 


\section{Impact of the Higher Education Act}

Although a recent federal statute ${ }^{73}$ directing educational institutions to deny federal financial aid to students convicted or participating in disruptive campus activities may be disliked by universitie $\mathrm{s}^{74}$ and is arguably discriminatory against the poor student in favor of the rich, ${ }^{75}$ its notice and hearing requirement ${ }^{76}$ encourages schools desiring to apply the federal sanction to develop a procedural scheme consistent with the minimal requirements of due process. However, schools presently providing substantial procedural protection but desirous of protecting their students' federal financial aid may be encouraged to ignore their own notice and hearing procedures to avoid the mandatory directive of the statutes.

Forty-six percent of the schools replying to the questionnaire indicated that they would obey the statute, while only six percent asserted that they would never enforce it. Perhaps the 42 percent not responding to the question would obey the statute if fully informed of its provisions and its applicability to their activities. A substantial

73. Higher Education Amendments of $1968 \S 504(\mathrm{a}), 20$ U.S.C. $\S 1060$ (a) (Supp. IV, 1969).

If an institution of higher education determines, after affording notice and opportunity for hearing to an individual attending, or employed by, such institution, that such individual has been convicted by any court of record of any crime which was committed after October 16, 1968, and which involved the use of (or assistance to others in the use of force, disruption, or the seizure of property under control of any institution of higher education to prevent officials or students in such institution from engaging in their duties or pursuing their studies, and that such crime was of a serious nature and contributed to a substantial disruption of the administration of the institution with respect to which such crime was committed, then the instituion . . . sball deny for a period of two years any further payment to, or for the direct benefit of, such individual under [certain designated federal student aid programs]. If an institution denies an individual assistance under the authority of the preceding sentence of this subsection, then any institution which such individual subsequently attends sball deny for the remainder of the two-year period any further payinent to, or for the direct benefit of, such individual under any of the programs [designated]. Id. (emphasis added).

Illinois has passed the following analogous statute devoid of section 504(a)'s notice and hearing requirements: "If the holder of [a state] scholarship . . participates in any disorderly disturbance ... against the administration ... using means which are not protected by the Constitution of this State or of the United States, his scholarsbip is thereby revoked. . . ."ILL. ANN. STaT. ch. 122, § 30-17 (Smith-Hurd, 1961). See generally Saxbe, Student Unrest and the Law, 18 CLEV. ST. L. REV. 429 (1969).

74. See Comment, Higher Education and the Student Unrest Provisions, 31 OHo ST. L.J. 111,117 (1970).

75. See id.; ABA RePORT 34-35.

76. Sce note 73 supra. 
majority of the schools replying may, therefore, be influenced in their decisions to provide notice and a hearing by the strictures of the statute. Indeed, it would be ironic if the statute influences schools sympathetic with its obvious punishment purpose to offer students at least minimal due process of law while institutions sympathetic to students' financial necessities and willing to give a student a second chance, though determined to provide a campus sanction, ignore due process to avoid mandatory elimination of federal educational assistance. ${ }^{77}$ To escape such a dilemma until the courts have interpreted the statute, universities might apply the vague language in the act, such as the words "serious" and "substantial,"78 to negate the statute's intended applicability. ${ }^{79}$

\section{Open $v$. Closed Hearings}

The student has no right to a public hearing, ${ }^{80}$ but such an open hearing might enhance the possibility that the decision of the hearing board would be more readily accepted by the student involved and the university community. Colleges have convincingly argued that this matter should be left to their discretion since they are best able to judge whether public hearings would cause disorder on campuses and interfere with educational functions. ${ }^{81}$ Closed hearings, however, must be more than informal interviews to accord with due process requirements. ${ }^{82}$ Presumably this means that the procedure of calling a student before a single administrative official, hearing his explanation, and imposing a final sanction is unconstitutional..$^{83}$ One case has held, however, that a student subjected to such a procedure

77. The statute seems to mandate denial of federal aid only if notice and an opportunity for hearing are provided. Presumably, the failure to provide minimal due process would relieve a school of the necessity of revoking a student's federal financial aid.

78. See note 73 supra.

79. Cf. 31 OHio ST. L.J., supra note 74, at 122.

80. See Moore v. Student Affairs Comm., 284 F. Supp. 725 (M.D. Ala. 1968); Zanders v. Louisiana State Bd. of Educ., 281 F. Supp. 747 (W.D. La. 1968); Goldberg v. Regents of the Univ. of Calif., 248 Cal. App. 2d 867, 57 Cal. Rptr. 463 (Ct. App. 1967).

81. See 248 Cal. App. 2d 867, 57 Cal. Rptr. 463.

82. 294 F.2d 150; see 5 Houston L. Rev. 541 (1968).

83. But see Wright v. Texas So. Univ., 277 F. Supp. 110 (S.D. Tex. 1967), affd 392 F.2d 728 (5th Cir. 1968), in which the Fifth Circuit interpreted its ruling in Dixon by holding that a student who explained his actions to both the Dean and President of the university and was then expelled was not denied due process hecause he "offered no evidence to establish the inadequacy of such hearings or to show that he was prejudiced by the lack of more." Id. at 731 . 
must affirmatively show that he was prejudiced thereby in order to sustain his constitutional claim of procedural inadequacy. ${ }^{84}$

As indicated in the summary of findings, 49 percent of the schools responding have elected either to require closed hearings or to leave the matter to the discretion of the particular student charged. Thus, a significant number of universities are apparently willing to risk student criticism for failing to provide public hearings in order to assure a more orderly proceeding.

\section{Joint Trials}

The question of a student's right to be tried jointly with fellow demonstrators, or conversely, singly despite his participation in a mass demonstration, has not been expressly litigated ${ }^{85}$ Although the matter is presently left entirely to the discretion of the university, the advantages to, the college of a joint hearing are manifold. Time would be conserved, and all the proof could be presented at one time, thus alleviating the difficulty of preserving evidence. On the other hand, a joint hearing involving 30 or 40 defendants may easily become a focal point for student dissent and may catalyze further disruptions. Additional pressure for the holding of joint hearings may also come from the students themselves, who might feel that there is strength in numbers. Forty-seven percent of the universities replying allowed joint trials, while 20 percent explicitly rejected them. The remainder failed to respond to the question, possibly indicating an ad hoc approach to the issue.

\section{Composition of the Hearing Board}

Membership. The composition of the hearing board itself has been scrutinized by both courts and commentators. The question of the membership of the panel, as well as the question of whether persons otherwise members may bring charges or act as complaining witnesses, has been the subject of controversy. There do not seem to be any constitutional commands in determining who should be designated as members of the hearing board, but commentators have uniformly suggested that the panel be comprised of a cross section of

84. Id. Cf. Tantra v. McKenney, 226 Mich. 245, 197 N.W. 510 (1924); Woods v. Simpson, 146 Md. 547, 126 A. 882 (1924).

85. For a discussion of joint trials of criminal defendants, see Note, The Admission of a Codefendant's Confession After Bruton v. United States: The Questions and a Proposal for Their Resolution, 1970 DukE L.J. 329. 
the university community--students, faculty, and administrators. ${ }^{88}$ The rationale for this position is that since the inquiry of the panel concerns the university as an ongoing institution, those on the panel should reflect the divergent views of those in the academic community concerned with the proper functioning of the university. The inclusion of students on the hearing panel would legitimize it in the eyes of the charged student since he would be judged in part by his peers. Additionally, membership on the board of a person with legal training would aid in rendering evidentiary and other procedural decisions.

Tabulation of the student disorder questionnaires revealed that, although the composition of hearing boards ranged from totally administration personnel to all students, many included some form of cross-section of the campus community. Eighty-four percent included at least one student, while only 17 percent of the panels were composed solely of one of the tripartite campus elements. A commitment to include students and a tendency to integrate dominant campus groups on the board is clear.

Alleged Board Bias. The question of bias, on the other hand, presents a more difficult problem. Students have complained that they were denied a fair hearing because the hearing board included persons directly concerned with the students' prosecution. ${ }^{87}$ Generally, these claims of bias have met little success. In Jones v. State Board of Education, ${ }^{88}$ for example, the students' claim of bias was based on the fact that two members of the hearing board also testified against the students at the hearing. The court held that there was no violation of due process because the students failed to show any actual bias or prejudice by the board against the claimants.$^{89} 1 \mathrm{t}$ thus appears that due

86. See, e.g., Comment, Private Government on the Campus-Judicial Review of University Expulsions, 72 YAle L.J. 1363 (1963); 53 MinN. L. Rev., supra note 24, at $321 \mathrm{n} .111$; cf. Witherspoon v. United States, 391 U,S. 510 (1968).

87. See, e.g., Jones v. Board of Educ., 279 F. Supp. 190 (M.D. Tenn. 1968).

88. Id.

89. The court distinguished Wasson v. Trowbridge, 382 F.2d 807 (2d Cir. 1967), which stated impliedly at least that no member of the hearing panel should have participated in the investigation of the student's conduct. The Jones court stated that since the students did not positively show bias, "[t]here is no violation of procedural due process when a member of a disciplinary body at a university sits on a case after he has shared with other memhers information concerning the facts of a particular incident. . . This limited combination by a school administrative body of prosecutorial and adjuidicatory functions is not fundamentally unfair in the absence of a showing of other circumstances, such as malice or personal interest in the outcome of a case." 279 F. Supp. at 200. See Wright v. Texas So. Univ., 277 F. Supp. 110 (S.D. Tex. 1967). 
process does not require strict separation of functions although any combination of prosecutorial and adjudicatory roles will be closely scrutinized by the courts. ${ }^{90}$ Where at all possible, universities should avoid this highly suspect practice.

A majority of the schools replying to the questionnaire prohibited both a testifying school official and a university witness to sit on the board. Only 20 percent allowed the first practice, while 13 percent allowed the latter. However, even these figures indicate some acceptance of a highly questionable practice.

\section{Right to Counsel}

During the course of the hearing, the college should arguably permit the student to be represented by counsel who is permitted to participate fully in the proceeding, even if the college is not likewise represented. The authorities are far from unanimous on this point; however, since some cases have held that the presence of counsel is a necessary prerequisite to insure the fairness that due process demands, ${ }^{92}$ universities would be prudent to permit counsel in order to protect against subsequent judicial interference. The courts which have denied the right to counsel have assumed that the presence of a lawyer is not the sine qua non of a hearing that is "fundamentally

90. See 382 F.2d at 813 . The commentators have uniformly condemned this combination of functions as being both constitutionally questionable and unnecessary. See, e.g., Van Alstyne, supra note 12 , at 594 n.30.

91. Numerous cases have stated that due process does not require "defendant's" counsel to be present at university disciplinary hearings. See Madera v. Board of Educ., 386 F.2d 778, 786 (2d Cir. 1967), cert. denied, 390 U.S. 1028 (1968); Barker v. Hardway, 283 F. Supp. 228 (S.D.W. Va.), affd 399 F.2d 638 (4th Cir. 1968), cert. denied, 394 U.S. 905 (1969); Buttny v. Smiley, 281 F. Supp. 280 (D. Colo. 1968); Wasson v. Trowbridge, 382 F.2d 807, 812 (2d Cir. 1967). However, some of these cases are distinguishable in their factual situations from the present inquiry. In Barker, the hearing board did not have an adjudicative function, but was merely to find facts and make recommendations to the President and faculty who could act on them or not as they chose. Had the hearing board possessed an adjudicative role, the court implied that counsel would have been necessary. For a discussion of Barker, see 71 W. VA. L. REv. 187 (1969). In Madera, the court said that counsel was not necessary in a proceding before a hearing panel which was to decide whether a highschool student should be readmitted, transferred, or transferred with parents' consent to a school for maladjusted children. In Wasson, coneerning a student at the Merchant Marine Academy, the court admitted that the governmental interest in maintaining and instilling discipline was higher than at a non-military school.

92. See Dixon v. Alabama State Bd. of Educ., 294 F.2d 150 (5th Cir. 196I); Zanders v. Board of Educ., 281 F. Supp. 747 (W.D. La. I968); Esteban v. Central Mo. State College, 277 F. Supp. 649 (W.D. Mo. 1967). See generally Note, Right to Counsel in Public Welfare Hearings, 48 BostoN U.L. REv. 468 (I968). 
fair." ${ }^{\text {"93 }}$ The reason for this position most likely lies in traditional judicial unwillingness to intrude into university affairs due to a lack of expertise in academic matters and a belief that colleges should remain autonomous. ${ }^{94}$ Additionally, Dixon, cited in almost every subsequent case dealing with the right to counsel problem, did not impose a counsel requirement and specifically rejected the necessity of a "fulldress judicial hearing" 95 which the presence of counsel would seem to impose. Nevertheless, the recent cases upholding the requirement of counsel have undoubtedly relied on the traditional role that counsel fulfills in any judicial or quasi-judicial proceeding.96 It would seem that these latter authorities should be followed to assure the fair treatment of students and the affirmance of board decisions. ${ }^{97}$ There scems to be no authority, however, for the proposition that where the charged student cannot afford an attorney, the college should provide one.

Fifty-seven percent of the schools replying asserted that a student had the right to the assistance of counsel at a hearing. Ninety-one percent of those indicating that the student did not have the right to counsel nevertheless guaranteed his right to be accompanied by an advisor without legal training, and 74 percent indicated that there was no restriction on the type of non-legal advisor the student might have. Only three percent of the schools replied that they would provide

93. See, e.g., 386 F.2d 778; 283 F.Supp. 118.

94. Cf. Carr v. St. John's Univ., 34 Misc. 2d 319, 231 N.Y.S.2d 403 (Sup. Ct.), rev'd 17 App. Div. 2d 632, 231 N.Y.S.2d 403, 410, aff d mem., 12 N.Y.2d 802, 235 N.Y.S.2d 834, 187 N.E.2d 18 (1962); Anthony v. Syracuse Univ., 130 Misc. 249, 255, 223 N.Y.S. 796, 804 (Sup. Ct. 1927), rev'd, 224 App. Div. 487, 231 N.Y.S. 435 (1928); $c f$. McGuinis v. Walker, 40 N.E.2d 488 (Ohio Ct. App. 1941). In Anthony, the appellate division, in reversing the trial court, upheld an expulsion based on the administrative determination that the student involved was not a "typical Syracuse girl." The court stated that as long as the university was not acting arbitarily -it had some reason, even if not divulged, for the expulsion-and the expulsion would be upheld. 224 App. Div. at 491. One commentator has stated that "[r]egardless of the type of rationale employed by the courts . . . the overall impact of adjudication in student-university controversies has been characterized by judicial reluctanee to interferc with the action of the university." Goldman, The University and the Liberty of its Students-A Fiduciary Theory. 54 KY. L.J. 643, 654 (1966). See generally Van Alstyne, The Judicial Trend Toward Student , A cademic Freedom, 20 U. FlA: L. Rev. 290 (1968); Note, Expulsion of College and Professional Students-Rights and Remedies, 30 Notre Dame Law, 174 (1963); Comment, The College Studènt and Due Process in Disciplinary Proceedings, 13 S.D.L. REv. 87 (1968).

95. $294 \mathrm{~F} .2 \mathrm{~d}$ at 159.

96. See also French v. Bashful, 303 F. Supp. 1333 (E.D. La. 1969); Zanders v. Board of Educ., 281 F. Supp. 747 (W.D. La. 1968); Esteban v. Central Mo. State College, 277 F. Supp. 649 (W.D. Mo. 1967).

97. See 53 Minn. L. Rev., supra note 24, at 323. 
funds for an attorney if the student desired, with one-third of those basing their provisions of funds on the student's indigency. Fifty-four percent indicate $d$ that the administration had the right to be represented by counsel, while 21 percent asserted that it did not. Since the law is far from settled in the area, a majority of schools replying were at least in compliance with existing case law by affording the right to counsel to students at administrative hearings concerning campus disorders. But the data obtained from the questionnaire also indicate that a substantial number of schools prefer a situation where neither the student nor the administration is represented by counsel, a position possibly reflecting a dearth of legally-trained personnel to conduct a strict adversary proceeding and a fear of the complexity and formalism of such a proceeding.

\section{Confrontation and Cross-Examination}

There is authority for the proposition that a student should be able to confront and cross-examine the witnesses against him, ${ }^{98}$ although some courts have held that these procedural safeguards are not required. ${ }^{99}$ Were such a responsibility imposed, colleges have argued, it would be impossible to execute because of the university's inability to compel witnesses to appear and testify. Furthermore, even were witnesses to appear of their own volition, they would not be under oath in most instances and thus could not be punished for perjured testimony. ${ }^{100}$ However, in most of the recent cases confrontation and cross-examination of witnesses have been allowed before hearing boards with judicial approval. ${ }^{101}$ The advice to universities seeking to

98. As early as 1887 a court held that the student "was entitled to know what testimony had been given against him, and by whom it had been delivered, and that the proofs be made openly and in his presence, with a full opportunity to question the witnesses and to eall others to explain or contradict their testimony." Commonwealth ex rel. Hill v. McCauley, $3 \mathrm{~Pa}$. Co. Ct. 77,82 (1887). See Esteban v. Central Mo. State College, 277 F. Supp. 649 (W.D. Mo. 1967); In re Carter, 262 N.C. 360 , 137 S.E.2d 150 (1964).

99. The court in Dixon stated that "a full dress judicial hearing, with the right to crossexamine witnesses, is [not] required." 294 F.2d at 159. See State ex rel. Sherman v. Hyman, 180 Tenn. 99, 171 S.W.2d 822 (1942), cert. denied, 319 U.S. 748 (1943). There the court stated, "As to the right to meet his accusers face to face in an investigation of wrongdoing, we cannot fail to note that honorable students do not like to be known as snoopers and informers against their fellows . . . . In these circumstances they should not be subject to a cross-examination . . . ." 180 Tenn. at I10, 171 S.W.2d at 826. See also Wasson v. Trowbridge, 382 F.2d 807 (2d Cir. 1967); Steier v. New York State Educ. Comm'r, 27I F.2d I3 (2d Cir. 1959).

100. At least one court has accepted this argument. See State ex rel. Ingersoll v. Clapp, 81 Mont. 200, 263 P. 433, cert. denied, 277 U.S. 591 (1928).

101. See, e.g., Moore v. Student Affairs Comm., 284 F. Supp. 725, 731 (M.D. Ala. 1968); Zanders v. Board of Educ., 281 F. Supp. 747, 766 (W.D. La. 1968); Buttny v. Smiley, 281 F. 
preserve institutional autonomy and to avoid court interference should be obvious.

But it is not clear whether the student's attorney must be allowed to conduct the cross-examination. The most recent case which afforded the student the fullest panoply of procedural rights required only that the student himself be allowed to cross-examine, ${ }^{102}$ and no case has held that the student's counsel must be permitted to crossexamine university witnesses. ${ }^{103}$ If, despite the foreg oing, the university chooses to present its case against the charged student by the reports of complaining witnesses, the student must be furnished the names of these witnesses and an oral or written report of their testimony ${ }^{104}$ to aequire some idea of the adverse evidence.

Eighty-one percent of the schools replying recognized a student's right to hear the evidence against him, while only one percent did not provide such a right. Ninety percent of those refusing to allow the student to hear the evidence against him did furnish the student with the names of those testifying or a report of what was said by them. Since the right to confrontation is not yet settled in this context, only 10 percent of those replying have procedures clearly violative of present law. Of those schools recognizing a student's right to counsel, only 77 percent allowed such counsel to cross-examine administration witnesses as to all matters in question. Ninety-two percent of those schools which did not allow cross-examination by the student's counsel did allow the student to cross-examine, while only eight percent rejected both alternatives. Such liberal enforcement of the right of confrontation and cross-examination contrasts sharply with the fact that only 24 percent of the schools replying maintained the right of compulsory process, 47 percent indicating that they did not

\footnotetext{
Supp. 280, 288 (D. Colo. 1968).

102. Esteban v. Central Mo. State College, 277 F. Supp. 649, 652 (W.D. Mo. 1967).

103. At least one commentator has strongly urged, however, that therc appears to be no valid reason why counsel should not be permitted to cross-examine. Professor Van Alstyne has stated: "There appears to be little reason to forbid so customary a function of counsel, reserving to the hearing board substantial discretion to limit counsel's participation to avoid unreasonable delay, harassment, or simple grandstanding." Van Alstyne, supra note 1, at 594 n.29.

104. Dixon v. Alabama State Bd. of Educ., 294 F.2d 150, 159 (5th Cir. 1961). See State ex rel. Sherman v. Hyman, 180 Tenn. 99, 109-10, 171 S.w.2d 822, 826 (1942). See generally Developments in the Law-A cademic Freedom, 81 HARv. L. Rev. 1045, $1140-41$ (1968); Note, School Expulsions and Due Process, 1 Ind. Legal F. 413, 423 (1968); 53 MiNn. L. Rev., supra note 24, at 322-23; 38 NOTRE DAME LAW., supra note 94, at 181 (discussion of a student's right to confront and cross-esamine the witnesses against him). See also General Order, 45 F.R.D. 133, 147 (W.D. Mo. 1968) (en banc).
} 
maintain the prerogative of compelling students or staff to appear as the charged student's witnesses. Colleges and universities are willing to recognize confrontation of witnesses and cross-examination, even though they apparently still overwhelmingly reject the right to apply compulsory process. Without compulsory process the efficacy of confrontation and cross-examination is suspect.

\section{Right to Introduce Favorable Testimony}

Favorable Witnesses. The student must be allowed to present the oral testimony or written affidavits of his own witnesses before the hearing panel. ${ }^{105}$ Since the function of the hearing panel is basically to discover particular facts to determine whether university regulations have been violated, the courts have held that students should be allowed to present their version of the factual circumstances to assure a fair evaluation. In balancing the student's interest in remaining in school against the possible interruption of university functions that a full hearing might engender, the courts have opted to allow a student to pursue his case through witnesses, a practice which impinges very slightly on institutional functions. ${ }^{108}$ Since presenting evidence through witnesses is the established manner of proceeding in adjudications, courts have readily accepted this procedure in the campus context.

Schools replying to the questionnaire also demonstrated a similar acceptance. Eighty-one percent of the schools replying recognized a student's right to testify and call witnesses on his own behalf; only one percent rejected such right.

Absence of Self-Incrimination Privilege. In presenting his case, however, it appears that the student may not exercise a privilege against self-incrimination even if he may be later subject to criminal prosecution for his activity. ${ }^{107}$ The single court which has focused on

105. See Wasson v. Trowbridge, 382 F.2d 807, 812 (2d Cir. 1967); Esteban v. Central Mo. State College, 277 F. Supp. 649, 651 (W.D. Mo. 1967); cf. Geiger v. Milford Independent School Dist., 51 Pa. D. \& C. 647 (C.P. Pike Co. 1944). But see Due v. Fla. A. \& M. Univ., 233 F. Supp. 396, 403 (N.D. Fla. 1963).

106. See, e.g., 294 F.2d at 159.

107. Furutani v. Ewigleben, 297 F. Supp. 1163 (N.D. Cal. 1969). In Furutani, students participated in campus disturbances for which they became subject to both institutional and criminal sanctions. They sought an injunction delaying campus hearings until after the completion of local procedings, arguing that in order to avoid expulsion they might be forced to incriminate themselves at the hearings. The court denied the injunction, citing Garrity v. New Jersey, 385 U.S. 493 (1967), as authority for the proposition that the students could well be able 
the question reasoned that the student might be able to exclude damaging statements made at campus hearings from introduction into evidence at subsequent criminal proceedings, thereby somewhat lessening the necessity for the privilege. ${ }^{108}$ The student whose alleged activities are violative of both campus rules and local law may incriminate himself to avoid expulsion and then attempt to rely on Garrity $^{109}$ to escape a later criminal conviction resulting from his earlier statements. This tortuous procedure appears legal but offers little security to students wishing to present all pertinent evidence.

Fortunately, 71 percent of the schools replied that they recognized a student's privilege against self-incrimination at the hearing, while only four percent positively rejected such right. Apparently, a majority of schools in practice refuse to place the student in the Procrustean dilemma of choosing between risking expulsion and providing the local authorities with prejudicial evidence.

\section{Evidentiary Requirements}

Rules of Evidence. In conducting the hearing itself the college is not required to follow any rules of evidence. ${ }^{110}$ However, commentators have suggested, and common sense would seem to demand, that some standards of relevance and materiality should be maintained to preclude the utilization of unreliable information."11

Results from the questionnaire reveal that 20 percent of the schools to some degree follow the evidence rules relating to hearsay, relevancy, and materiality. Ten percent reported that they followed all three rules as closely as possible, while only 17 percent acknowledged that they followed no specific legal rules in conducting their hearings. Although the actual practice is widely divergent, a substantial number of schools attempt at least a minimal structuring of the evidentiary portions of their hearings.

to exclude any self-incriminatory statements in subsequent local proceedings. See Madera v. Board of Educ., 386 F.2d 778 (2d Cir. 1967); Goldberg v. Regents of the Univ. of Calif., 248 Cal. App. 2d 867, 57 Cal. Rptr. 463 (1967). But see State ex rel. Sherman v. Hyman, 180 Tenn. 99, 171 S.W.2d 822 (1942), in whicb the court stated "students should not be compelled to give evidence incriminating themselves . . . Id. at 826. Sce notes 35-39 supra and accompanying text.

108. 297 F. Supp. at 1165.

109. 385 U.S. 493 (1967).

110. See Goldberg v. Regents of the Univ. of Calif., 248 Cal. App. 2d 867, 883, 57 Cal. Rptr. 463,475 (1967).

111. See 72 YALE L.J., supra note 85, at 1406-07; 53 MiNN. L. REV., supra note 24, at 324. 
Quantum of Proof. The hearing board must base its decision on "substantial evidence" 112 and only on the evidence presented during the proceedings. ${ }^{113}$ It should be noted, however, that seldom have the decisions of disciplinary panels been overturned by the courts on the basis that there was insufficient evidence to support the charges against the student..14 Nevertheless, one district court has called this "substantial evidence" rule one of the minimal requirements growing out of the concept of fundamental fairness implicit to procedural due process. ${ }^{115}$ This particular matter is seldom explicitly brought to the attention of the courts since the charged student's activities are frequently not a matter of serious doubt. The evidence of his participation in the disruptive activities is often not only substantial but overwhelming. ${ }^{116}$

Burden of Proof. The question of who has the burden of proof in a disciplinary hearing has seldom been explicitly litigated, although proceedings have been upheld in which the student was expected to convince the administration of his innocence. ${ }^{117}$ In practical terms, the burden of proof issue may not be critical to the defendant-student

112. The court in Scoggin v. Lincoln Univ., 29l F. Supp. 161 (W.D. Mo. 1968), quoted its own General Order for the conclusion that "no disciplinary action [may] be taken on grounds which are not supported by any substantial evidence." Id. at 171.

113. In Esteban v. Central Mo. State College, 277 F. Supp. 649 (W.D. Mo. 1967), the court stated that the "President shall determine the facts of each case solely on the evidence presented at the hearing . . . "Id. at 652. But see Jones v. Board of Educ., 279 F. Supp. 190, 200 (M.D. Tenn. 1968). There the court suggested that divulging of information concerning the particularities of the facts of a specific case by one board member to another would not violate due process.

114. But see 291 F. Supp. at 167-70; Knight v. Board of Educ., 200 F. Supp. 174, 180-81 (M.D. Tenn. 1961).

115. General Order, supra note 18 , at 147.

116. See, e.g., 248 Cal. App. 2d at 871 n.4, 57 Cal. Rptr. at 466 n.4. But see 291 F. Supp. 161 , in which the university charged Scoggin with planning and participating in a demonstration which led to the destruction of university property. However, the university did not show that Scoggin planned a violent demonstration or himself destroyed any property. The court stated that there was no substantial evidence to prove anything except that Scoggin planned a peaceful demonstration which had been previously impliedly authorized by the President. Id. at 169. The court therefore ordered reinstatement.

117. In Jones v. Board of Educ., 279 F. Supp. 190 (M.D. Tenn. 1968), the students argued that they were denied due process because the question to be decided by the hearing board was whether the students would be readmitted thus placing the burden on the plaintiff students. The court summarily rejected this argument, stating that "[d]isciplinary proceedings conducted by an educational institution are not to be tested according to the niceties of procedure required in a court of law. Inquiry into the technicalities governing burden of proof in civil or criminal trials is, therefore, irrelevant. Id. at 202. Accord, Cornette v. Aldridge, $408 \mathrm{~S}$. W.2d 935, 942 (Tex. Ct. Civ. App. 1966). But see Commonwealth ex rel. Hill v. McCauley, 3 Pa. Co. Ct. 77, 82 (1887). 
even with the substantial evidence rule noted above, ${ }^{118}$ since only one percent of the schools replying place the burden on the student to establish his innocence. Forty-four percent of the institutions placed the burden of proof on the administration to establish the guilt of the student. Of the 45 percent responding fully to the burden of proof question, a substantial majority required either proof of guilt beyond a reasonable doubt or upon a preponderance of the evidence, quantums of proof presumably well within the judicial standard of "substantial evidence." Fifty-five percent of the replies failed to identify the party with the burden of proof, perhaps indicating an absence of any consistent test.

Limitations on Evidence Considered. On the other hand, the requirement that the panel decide the issue at hand solely on the evidence presented has been litigated more frequently. ${ }^{119}$ This problem frequently occurs in a small community, such as a university, where members of the hearing panel are likely to have some previous knowledge of the specific factual circumstances surrounding the activities of the students being heard. However, board members must not rely on their own first-hand knowledge of the facts. This issue is somewhat similar to the discussion above ${ }^{120}$ concerning board members combining adjudicatory and prosecutorial roles. It seems inevitable that in such situations the panel member will have at least an implicit personal interest in the outcome of the case and thus will not be impartial. ${ }^{121}$ To the extent that such partiality can practically be obviated by not allowing complaining witnesses to sit on the hearing board, the proceedings will be fairer. Furthermore, the members of the board should not base their decision on confidential reports which the charged student does not have the opportunity to sce or rebut. Of course, if the student is given the name of the informant and an oral or written report of the informant's testimony, the evidentiary and confrontation problems would most likely be lessened if not eliminated. ${ }^{122}$

Seventy-three percent of the replying institutions reported that only evidence presented at the hearing was considered in determining a student's guilt or innocence; only six pereent answered that their

118. See notes 112-16 supra and accompanying text.

119. Cf. notes 86-90 supra and accompanying text.

120. See id.

121. See Van Alstyne, supra note 1, at 594 n.30,

122. See note 104 supra and accompanying text. 
hearing decisions were based at least partially on evidence acquired outside the hearing, a practice violative of prcsent law.

\section{Moral Justification}

In keeping with the standard of "fundamental fairness" announced in the cases, ${ }^{123}$ it is desirable to permit the charged students to testify concerning moral justifications, motives, and reasons for their acts to assist in the determination of the appropriate sanction. Such explanations serve both the student, as mitigating factors, and, at least in theory, the university, as a release of student grievances concerning alleged campus injustices.

Forty-nine percent of the schools replying indicated that they allowed such evidence on the issue of guilt or innocence; 50 percent allowed it on the issue of appropriate sanction. Ninetcen percent rejected this type of evidence in determining innocence or guilt, while only 10 percent explicitly rejected it in determining the proper sanction. Based on the questionnaire sample, at least one-half of American colleges and universities are willing to accept moral jusitification as direct evidence in a campus disorder hearing, although such evidence is generally irrelevant in establishing a student's guilt or innocence. Admission of such evidence on that latter issue hardly comports with the goal of reliably determining the truth or falsity of the charges. Extensive admission of such evidence on all issues raised at the hearing, converting the proceedings into a political for um, could lessen their value as a fact-seeking mechanism. Indications from the questionnaire that such a practice is prevalent within a substantial number of colleges and universities is ground for serious concern unless closely monitored.

\section{Preparation and Dissemination of Transcript}

For the student to prosecute an effective appeal from the decision of the hearing board, the university should provide a transcript of the proceedings. Due process does not require that such a stenographic or mechanical recording be made, ${ }^{124}$ but both the college and the charged

123. In Jones v. Board of Educ., 279 F. Supp. 190, 205 (M.D. Tenn. 1968), the court states, "It is axiomatic that the exigencies of university life require the formulation and enforcement of rules of student conduct, and a court of law will not interfere with this function when ... the university has proceeded in a manner that is fundamentally fair and reasonable." Id. at 205. See Moore v. Student Affairs Comm., 284 F. Supp. 725 (M.D. Ala. 1968); Kobiltz v. Western Reserve Univ., 11 Ohio C.D. 515 (Cir. Ct. 1901).

124. See 233 F. Supp. at 403. 
student must be permitted to record the proceedings at their own expense. ${ }^{125}$ At least one commentator has suggested that in order to insure fairness and facilitate an appeal, a simple tape recording of the entire proceedings could be made from which a typed transcript could be prepared if necessary. ${ }^{126}$

Fifty-three percent of the schools replying allowed the student to make a transcript of the hearing, and 20 percent expressly denied the student such a right, thus directly rejecting present case law. Fortynine percent provided a transcript for a student financially unable to provide one himself; only 21 percent directly refused such a service. Again, the statistics demonstrate that a substantial number of schools have adopted procedures superior to the current law in the area, thereby enabling a student to appeal effectively from an adverse hearing board decision.

\section{Publication of Hearing Board Decision}

Once a decision has been reached by the hearing board, the results of the proceedings must be written, ${ }^{127}$ made public, and made available for the student's inspection..$^{128}$ Only 36 percent of the schools replying indicated that they performed such a function. Furthermore, the board must make specific findings as to the student's guilt or innocence of the conduct charged, ${ }^{129}$ presumably to enable the student to prepare specific objections to these findings and thus prosecute an effective appeal to a higher administrative authority. Only 58 percent of the schools replying reported that they prepared specific findings, 19 percent indicating that they definitely did not, thereby revealing a continuing practice which is undesirable if not illegal.

\section{Post-Hearing Rights: Appellate Review}

No case has held that a college must provide for institutional review of the hearing panel's decision, but procedures embodying such an appellate framework have been impliedly endorsed by courts which state that the student has a right to make a transcript of the

125. See 277 F. Supp. at 652.

126. Van Alstyne, supra note 1, at 594 n.32. Professor Van Alstyne's suggestion, in light of its simplicity and ease of administration, seems desirable to obviate disputes over the evidence presented at the hearing.

127. Esteban v. Central Mo. State College, 277 F. Supp. 649,652 (W.D. Mo. 1967).

128. 294 F.2d at 159; Woody v. Burns, 188 So. 2 d 56 (Fla. Dist. Ct. App. 1966), citing, 233 F. Supp. 396.

129. 277 F. Supp. at 652. 
proceedings before the hearing panel. ${ }^{130}$ It would appear that some appellate procedure would be desirable from both the student's and the administration's point of view. Appellate review would benefit the student by serving as a safeguard against individual arbitrariness of the hearing panel and aid the university by correcting procedural errors which, if left unanswered, might result in judicial intervention and reversal on petition of the students involved. To accomplish these ends, a procedure of automatic review by the President or other higher university official would be adequate and desirable ${ }^{131}$

Fifty-seven percent of the institutions replying to the questionnaire asserted that they provided some type of appellate procedure for students charged with violation of university regulations concerning campus-wide disorders. Only three percent answered that they provided no such appellate review. As shown on the summary of results, the grounds for review varied greatly, but a tendency can be discerned to allow appeal on any grounds or on the basis of error in procedure at the hearing. Appeal based on new evidence or excessive punishment also received significant support among the schools replying to the questionnaire. The president of the university was the most popular choice as a campus appellate agency with substantial responses also supporting the board of trustees or an appeal committee. The high percentage of "no responses" to the appellate review questions possibly indicate a lack of any uniform procedure.

\section{CONCLUSION}

Though many schools have kept pace with legal developments in the student disorder area or even advanced ahead of such developments, results of the questionnaire reveal that many existing procedures fail to satisfy even the minimal current requirements of due process. The survey justifies the initial evaluation that most schools desire both to treat students fairly within the law and to protect life and property through the application of reasonable judicial procedures. Departures from the present state of the law concerning collegiate due process have been noted throughout. Whether or not a particular institution desires and needs a detailed judicial code, it is believed that no school should engage in a systematic disregard of the law or consistently apply fundamentally

130. Id; see Goldberg v. Regents of the Univ. of Calif., 248 Cal. App. 2d 867, 882, 57 Cal. Rptr, 463, 474 (1967).

131. See generally.72 YALE L.J., supra note 85, at 1407-08. 
unfair procedures to its students. It is sincerely hoped that this project will contribute to the termination of such practices wherever they exist and encourage all colleges and universities to explore the possibility of providing fairer, more effective, and more efficient means of handling allegedly disruptive students within the chaos often precipitated by campus disorders. 